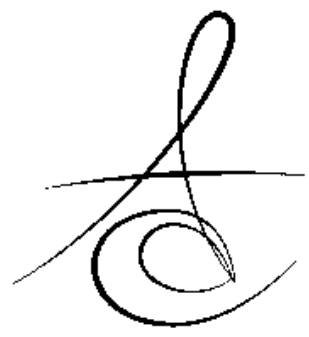

\title{
ORAL SKUAMÖZ HÜCRELİ KARSİNOM: 3 OLGU SUNUMU VE LİTERATÜR DERLEMESİ
}

\section{ORAL SQUAMOUS CELL CARCINOMA: 3 CASE REPORT AND REVIEW OF LITERATURE}

\section{Dt. Berceste POLAT AKMANSOY* Dt.Merve DÖNMEZ ŞAKIR*}

\author{
Prof. Dr. Filiz NAMDAR PEKİNER \\ Prof. Dr.Canan ALATLI**
}

öz

Skuamöz hücreli karsinom, oral kavitede en sık izlenen malignitedir. Ağız mukozasının her bölgesinde görülebilen bu karsinomlarda tütün ve alkol tüketimi önemli etkendir. Bu makalede son altı ay içinde kliniğimizde tanısı konan, lokalizasyonları bakımından farklı üç oral skuamöz hücreli karsinom olgusu literatür bilgileri doğrultusunda sunulmuştur.

Anahtar kelimeler: Skuamöz hücreli karsinom, oral kavite, dişeti mukozası, dil mukozası

\section{ABSTRACT}

Squamous cell carcinoma is the most common malignancy affecting the oral cavity. Tobacco and alcohol consumption in these carcinomas can be seen in every region where the oral mucosa is an important factor. This article in the latest issue of our clinic diagnosed within six months in terms of localization of three different oral squamous cell carcinoma are presented in accordance with the literature.

Key words: Squamous cell carcinoma, oral cavity, gingiva, tongue

karsinom oluşturmaktadır. Oral skuamöz hücreli karsinom (SHK) oral mukozanın sıklıkla rastlanan malign neoplazmaları olup tüm malign lezyonların \% 3-5'ini oluşturmaktadır. Oluşumunda tütün kullanımı, alkol tüketimi, siroz, ultraviole ışığı, kronik travmalar, kötü ağız hijyeni, virüsler önemli etkenlerdir. ${ }^{3-10}$

Sıklıkla mukozada gelişen oral skuamöz hücreli karsinom zamanla daha derin dokulara, komşu yumuşak dokulara, lenf bezlerine, sinirlere, kan damarlarına ve kemiğe yayılabilmekte lokal destrüktif büyüme ve metastaz yapabilmektedir. Küçük lezyonlar genellikle başlangıçta asemptomatik olup büyüdükçe ağrı, parestezi, şişlik gibi belirtiler izlenebilmektedir. Kemiğe invaze olanlar radyografik olarak sınırları belirgin olmayan, düzensiz, litik lezyonlar şeklinde görüntü verebilmektedir. Metastaz ise genellikle lenfatik yolla, sıklıkla submandibular ve submental lenf nodülleri ile olmaktadır. Skuamöz hücreli karsinom lokalizasyonuna göre dil, dudak, sert damak, yumuşak damak, gingiva, retromolar üçgen ve ağız tabanı şeklinde sınıflanabilir.,11-14

\footnotetext{
*Marmara Üniversitesi, Dişhekimliği Fakültesi, Ağız,Diş ve Çene Radyolojisi AD. İstanbul

** İstanbul Üniversitesi, Onkoloji Enstitüsü, Onkolojik Sitoloji ve Tümör Patolojisi Bilim Dalı, İstanbul
} 
Histopatolojik olarak az-orta veya iyi differansiye olarak derecelendirilen tümörlerdir. Tümör dokusu en üstte kısmen veya yaygın keratin içerebilir, bazı olgularda ise nekrotik artıklarla kaplı ülser görülebilir. Geniş sitoplazmalı, iri nükleuslu tümör hücreleri bağ dokusu içinde, bağımsız veya birbiriyle bağlantılı irili ufaklı adalar oluşturur. Tümör adalarının dış kenarındaki hücreler normal epitelin bazal tabakalarını taklit eder şekilde, nükleusları daha koyu boyanan, biraz daha küçük hücrelerdir. 3,4,13

Tedavi temel olarak cerrahidir. Lezyon emniyet sınırı ile birlikte eksize edilir. Radyoterapi ve bazen kemoterapi uygulanması ile tam kür sağlamaya çalışılır. Erken tanı ve tedavi olanaklarındaki gelişmelere rağmen prognoz kötü olup 5 yıllık sağ kalım oranı \% 50-55 civarındadır. Yapılan çalışmalarda oral ve farengeal kanserlerin \% 53'ünde uzak metastaz bildirilmiştir. ${ }^{15-17}$

$\mathrm{Bu}$ makalede son altı ay içinde kliniğimizde tanısı konan lokalizasyonları bakımından farklı üç oral skuamöz hücreli karsinom olgusu literatür bilgileri doğrultusunda sunulmuştur.

\section{OLGU 1}

Kliniğimize dilinin sağ lateral $1 / 3$ orta-ön kısmında yemek yeme, konuşma sırasında ağrı ve yanma hissi nedeni ile başvuran 40 yaşındaki kadın hasta yaklaşık 1.5 yıl önce de aynı şikayetlerle dermatoloji kliniğine başvurduğunu ve kenacord orabase pomad ile piraldine reçete edildiğini bildirmiştir. Alınan anamnezinde sigara ve alkol kullanmadığı saptanan hastanın demir ve $\mathrm{B}_{12}$ vitamin eksikliği nedeni ile ilaç kullandığı belirlenmiştir. Hastanın ekstraoral muayenesinde palpasyonda submandibular lenfadenopati, intraoral muayenesinde yaklaşık $2 \mathrm{~cm}$. çapında tabanında pigmentasyon izlenen sınırları belirgin hafif hiperplazik beyaz plaklar arasında atrofik alanlar saptanmıştır (Resim 1).

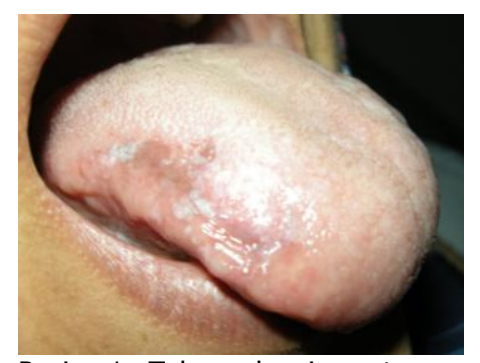

Resim 1. Tabanında pigmentasyon izlenen sınırları belirgin hafif hiperplazik beyaz plak arasında atrofik alanlar
Hastaya lokal anestezi altında punch biyopsi uygulanmış ve alınan doku örneği İstanbul Üniversitesi, Onkoloji Enstitüsü, Onkolojik Sitoloji ve Tümör Patolojisi Bilim Dalı'na histopatolojik değerlendirme amacıyla gönderilmiştir. Doku örneğinin incelenen kesitlerinde yapısal ve hücresel displazik değişiklikler, epitelin altında atipik spinal tabaka hücrelerinin oluşturduğu küçük adacıklar ve çevrelerinde yoğun kronik iltihap hücresi infiltrasyonu ve bir alanda infiltrasyonun kas içine doğru ilerlediği gözlenmiştir. İmmun histokimyasal panel tarif edilen atipik hücrelerde pozitif'dir. Histopatolojik tanı oral skuamoz hücreli karsinom olan hastadan pozitron-emisyon tomografisi (PET-CT) ve baş-boyun bölgesi lenf bezlerinin değerlendirilmesi amacıyla ultrasonografik (USG) muayene istenmiştir. PET-CT değerlendirmesinde dil sağ lateralinde bilgisayarlı tomografide (BT) karşılığı net demarke edilemeyen çok düşük yoğunlukta tutulum alanı ve boyun bölgesinde sağ mandibular alanda 19 mm çapında hipermetabolik karsinömatöz oluşum lehine değerlendirilen lenfadenopati (LAP) kitlesi saptanmıştır (Resim2).

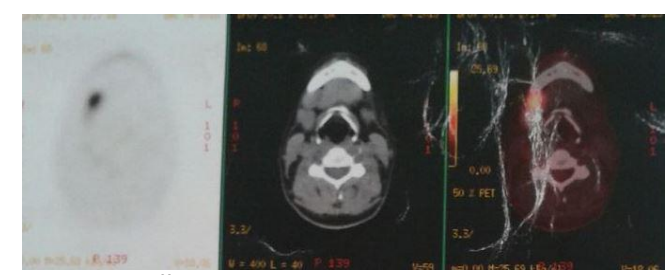

Resim 2. Sağ mandibular alanda hipermetabolik karsinömatöz oluşum lehine değerlendirilen LAP kitlesi

USG incelemesinde sağ submandibular alanda orta hattın hemen sağında ve mandibular kemiğe hemen bitişik alanda $24 \times 13 \mathrm{~mm}$ ve $3.5 \times 2 \mathrm{~mm}$ boyutlarında hipervasküler karakterde iki adet LAP izlenen hasta opere edilmek üzere yönlendirilmiştir.

\section{OLGU 2}

Kliniğimize başvurmadan yaklaşık 15 gün önce sol maksilla posterior bölge bukkal yüzeyde bir kabarıklık hisseden 77 yaşındaki bayan hasta kabarıklığın olduğu alanın soğan kabuğu gibi ayrılmaya başlaması üzerine tavsiye ile kenacord orabase pomad kullanmış ancak herhangi bir değişiklik olmayınca kliniğimize başvurmuştur. Sistemik anamnezinde hipertansiyon nedeniyle ilaç kullandığı saptanan hastanın intraoral muayenesinde sol maksillar molar dişlerin bukkalinde yoğun hiperkeratinize nodüler ve palatinal mukozada eroziv nodüler alanlar izlenmiştir (Resim 3a-b). 


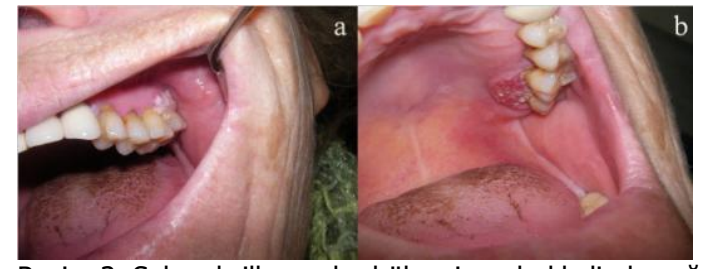

Resim 3. Sol maksillar molar bölgenin a. bukkalinde yoğun hiperkeratinizasyon ve $b$. aynı bölgenin palatinalinde eroziv nodüler alanlar

Ekstraoral muayenede palpasyonda lenfadenopati ya da herhangi başka bir patolojik bulgu saptanmamıştır. Hastadan yapılan smear incelemesinde yayma lamlarda fibrin ve eritrositten zengin zemin üzerinde polimorf nötrofil, lenfosit ve histiyosit, çok sayıda keratinize yassı epitel hücresi arasında, bazıları iri çekirdekli, granüler kromatinli, bazıları piknotik çekirdekli, çoğu koyu eozinofil, bazofil stoplazmalı, yuvarlak, iğsi, tek uzantılı veya yıldızsı biçimli atipik yassı epitel hücreleri izlenerek sitopatolojik tanının doğrulanması için biyopsi yapılması önerilmiştir (Resim $4 a-b)$.

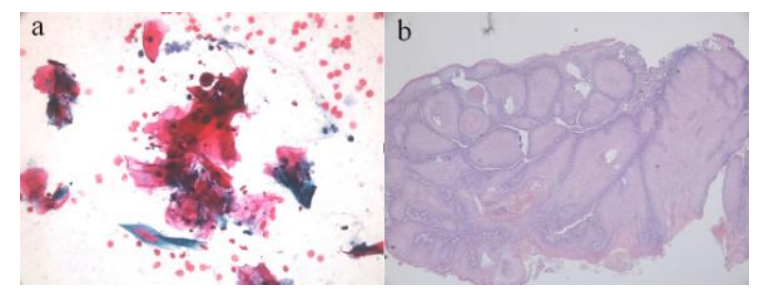

Resim 4: a. Keratinize yassı epitel hücresi arasında, bazıları iri çekirdekli, granüler kromatinli, bazıları piknotik çekirdekli, çoğu koyu eozinofil, bazofil stoplazmalı, yuvarlak, iğsi, tek uzantılı veya yıldızsı biçimli atipik yassı epitel hücreleri (Pap x400), b. Atipik yassı epitel hücrelerinden oluşan belirfin nükleolus içeren hücreler, diskeratotik hücreler, bazlarının ortasında konsantrik keratin lamelleri, çevresinde çok sayıda lenfosit ve plazma hücresi izlenmektedir (HE X40).

Hastadan histopatolojik inceleme amacıyla ilgili alandan lokal anestezi altında insizyonel biyopsi yapımış, alınan doku örneği İstanbul Üniversitesi, Onkoloji Enstitüsü, Onkolojik Sitoloji ve Tümör Patolojisi Bilim Dalı'na gönderilmiştir. Histopatolojik tanı skuamöz hücreli karsinomdur. Hastanın PET-CT bulguları boyun imajlarında üst çene maksillada sol molar diş düzeyinde, dişetine doğru uzanım gösteren, ekspansif görünümlü, $2 \times 2.5 \mathrm{~cm}$ boyutlarında artmış Flor18-DeoksiGlukoz (FDG) tutulumu ile karakterize hipermetabolik alan izlenmiş olup bu odak dışında boyunda servikal ve juguler zincirlerde patolojik boyut ve aktiviteli lenf noduna rastlanan (Resim 5) hasta opere edilmek üzere yönlendirilmiştir.

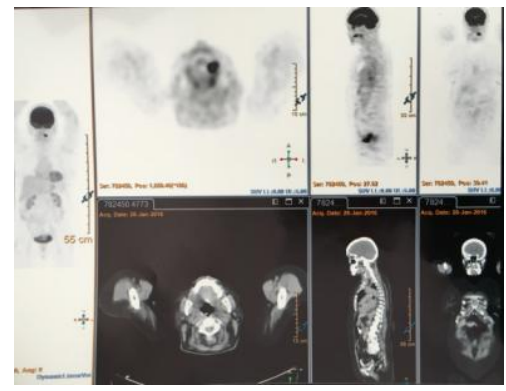

Resim 5. Üst çene maksillada sol bölgede ekspansif görünümlü hipermetabolik alan

\section{OLGU 3}

63 yaşında erkek hasta yaklaşık 5 yıldır mevcut olduğunu belirttiği sağ dudak köşesinde lokalize beyaz renkli alanda baharatlı ve asitli yiyeceklerden hassasiyet hissetmesi nedeniyle kliniğimize başvurmuştur. Mevcut değişimin son bir yıldır daha büyüdüğünü belirten hasta da sistemik herhangi bir bulgu saptanmamıştır. 40 yıldır günde bir paket sigara tüketen hasta yaklaşık 15 yıldır alkol kullanmadığı belirtmiştir. İntraoral muayenesinde sağ dudak komissuradan yanak içine doğru ilerleyen yüzeyi düzgün olmayan girintili çıkıntılı hiperkeratinizasyon ile belirgin nodüler eroziv alanlar izlenmiştir (Resim 6).

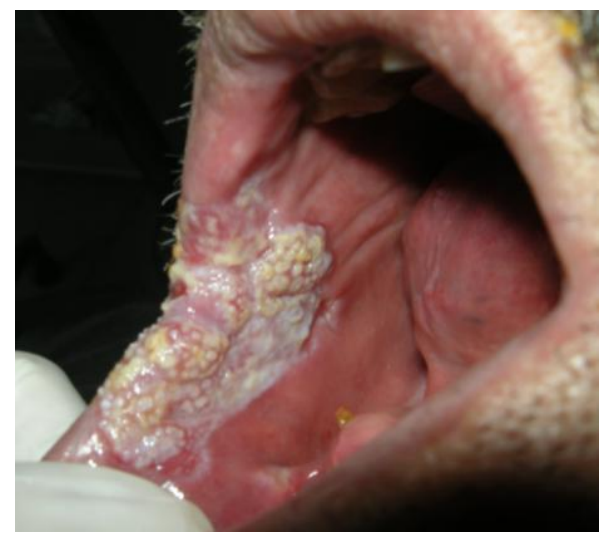

Resim 6. Sağ dudak komissurasından yanak içine doğru ilerleyen yüzeyi düzgün olmayan girintili çıkıntılı hiperkeratinizasyon ile belirgin nodüler eroziv alanlar

Ekstraoral muayenede palpasyonda lenfadenopati ve herhangi başka bir patolojik bulgu saptanmamıştır. Hastaya histopatolojik inceleme amacıyla lokal anestezi altında insizyonel biyopsi yapılmış, alınan doku örneği İstanbul Üniversitesi, Onkoloji Enstitüsü, Onkolojik Sitoloji ve Tümör Patolojisi Bilim Dalı́na gönderilmiştir. İncelenen kesitlerde histomorfolojik bulguların skuamöz hücreli karsinom ile uyumlu olduğu

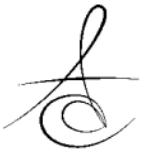


belirtilmiştir. Hastanın USG incelemesinde herhangi bir patolojik bulgu saptanmaz iken, PET-CT bulguları üst dudak sağ lateral kesiminde izlenen fokal orta yoğun seviyelerde metabolik aktivite primer lezyon lehine değerlendirilmiştir. Hasta opere edilmek üzere yönlendirilmiştir.

\section{TARTIŞMA}

Skuamöz hücreli karsinom oral kaviteyi döşeyen çok katlı yassı epitelde displazi ile başlayan ve neoplazik hücrelerin bazal membranı aşarak supepitelyal alana invaze olması ile gelişen malign bir tümördür. 40 yaş sonrası erkeklerde daha sıklıkla rastlanmaktadır. $\mathrm{Bu}$ karsinomun etyopatogenezinde ekstrensek ve intrensek birçok faktörün etkili olduğu bildirilmektedir. Yoğun tütün (sigara, puro, nargile, pipo, çiğneme tütünü [areka cevizi/felfelek, Maraş otu] ) ve alkol kullanımı, ultraviyole ışınları, human papilloma virüsü, sifiliz, kimyasal ürünler ile uzun süreli çalışma, kötü ağız hijyeni, meyve-sebzeden fakir diyet, besinlerdeki uygunsuz katkı maddeleri, immunosupresifler ile kötü yapılmış protetik uygulamalar olarak sayılabilir.,13,15-17 Bizim olgularımızın ise 2'si kadın 1'i erkek birey olup sadece erkek olguda yoğun sigara kullanımı olduğu saptanmıştır. Ancak ilk olgumuzda $\mathrm{B}_{12}$ ve demir eksikliği olduğunun saptanması mukozada atrofiye neden olan hastalıkların kanser riskini yükselttiğini, demir eksikliği anemisi, $B_{12}$ vitamini eksikliği, eroziv liken planus gibi olgularda atrofik mukozanın direkt bir faktör olmamakla beraber normal mukozaya göre malignite kazanabilme olasılığını arttırabildiğini ortaya koyması bakımından önemlidir. ${ }^{3}$

Klinik olarak eksofitik (papiller,hipertrofik, verrüköz) olabildiği gibi, endofitik (ülseratik) formda kırmızı ya/ya da beyaz plak şeklinde izlenenbilen skuamöz hücreli karsinomların yaklaşık üçte birini ağız tabanında oluşmaktadır. Genellikle bu bölgedeki premalign lezyonlardan sonra gelişen karsinomlar, özellikle lingual frenulum ve sublingual bezin kanal ağızları etrafında yerleşir ve kenarları sert ve düzgün olmayan, ülsere benzer bir lezyon olarak gözlenir. İleri evrelerde dişetine ve dil altına doğru ilerleyebilir ve dil hareketlerinde kısıtlama yaratabilir. İlerlemiş olgularda submandibular lenf düğümlerine, jugulo-digastrik lenf düğümüne ve boyun lenf zincirinin üst/ alt düzeydeki dokularına yayılma yapabilirler. Dilde ise özellikle dilin posterolateral ve ventral yüzeylerinde meydana gelir.
Yumuşak damak ve retromolar bölge bu karsinomların yaklaşık \% 15'inin gözlendiği bölgelerdir. Yapışık dişeti ve alveolar gingival mukoza da izlenme olasılığı \% 5, bukkal mukozada ise \% 2 kadardır. Sert ve yumuşak damakda ise bu lezyonların \%71'inin yumuşak, \%29'unun sert damakta meydana geldikleri bildirilmektedir. Yumuşak damakta lezyonu olan hastaların \%40'ında, sert damakta lezyonu saptananların ise \%13'ünde bölgesel lenf nodu metastazları görüldüğü bildirilmektedir. ${ }^{3,18-21} \mathrm{Bu}$ makale olguları klinik ve lokalizasyon bakımından birbirinden farklı olmakla beraber literatür bulguları ile uyumludur.

Oral kavitenin en sık rastlanan malignomu olan skuamöz hücreli karsinomun genellikle geç dönemlerde radyolojik olarak belirlenebilen osteolitik değişiklik yaptığı gözlenmektedir. Bu nedenle konvansiyonel radyografiler, USG, BT, magnetik rezonans görüntüleme (MRG) ve PET-CT incelemelerde negatif bulgu hiçbir zaman gerçekte malignom olmadığı anlamına gelmemektedir. Rastlantı bulgusu olarak kemik lezyonları bir malignom olasılığını işareti edebilir. Sınır belirginliği bulunmayan tüm radyolusent görüntüler, özellikle büyük alana yayılmış veya multiloküler sklerotik ve osteolitik görüntüler her zaman şüpheli olarak değerlendirilmelidir. ${ }^{3,18-21}$

Kemik konturlarının bozulması, kortikal kemiğin kaybolması, lamel veya dikensi çıkıntılar şeklindeki yeni kemik yapımı görüntüsü malign kemik tümörünün karakteristik görüntüsü olabilir. Mukozadaki bir ülserin altındaki kemikte osteolitik görüntü karsinomu düşündürmek için yeterli olabilir. Bu malignomlar osteolitik alan dışında sklerotik veya bunların kombinasyonu şeklinde de izlenebilen alanlar olarak da görülebilir. ${ }^{3,22,23}$ Bu makalede sunulan olgular PET-CT ve ultrasonografi ile değerlendirilmiş ve radyolojik olarak literatür bulguları ile uyumlu olduğu saptanmıştır.

Ağız kanserlerinde diğer tiplerinde olduğu gibi daha iyi sonuçlar ancak erken tanı ve buna bağlı erken tedavi oranlarının artmasıyla mümkün görülmektedir. Sürekli gelişen kemoterapötik, radyoterapötik ve cerrahi yöntemlere rağmen ağız kanserlerinde 5 yıllık iyileşme oranı dünya literatür ortalaması $\% 40$ civarında iken bu oran $2 \mathrm{~cm}$ 'den daha küçük lezyonlar için \%95'tir. ${ }^{3,17}$

Ağız kanserlerinin tedavisinde esas amaç; hastalıksız bir yaşam ve organların olabildiğince korunduğu fonksiyonel bir sonuç elde etmektir. Tedavide cerrahi, radyoterapi, kemoterapi veya bunların kombinas- 
yonları kullanılır. Tedavi yönteminin seçimi; hastalık lezyonunun lokalizasyonuna, yaygınlığına (lezyonun alanı/boyutu), hastanın yaşına, eşlik eden hastalıkların durumuna, histopatolojik özelliklerine göre yapılmalıdır. Bu bakımdan hücre tipi, diferansiyasyon derecesi, lenf nodlarının durumu, kemik invazyonu, cerrahi sınırlar/komşulukları önemlidir. Sadece çene kemiklerini tutmuş olsa bile olsa kanser sistemik bir hastalık tablosu olduğundan medikal onkolog, radyasyon onkoloğu ve cerrah tarafından multidisipliner bir yaklaşımla tedavi planlaması yapılmalıdır. ${ }^{3,24,25}$

\section{Berceste Polat Akmansoy, ORCID ID:0000-0003-2330- 7745}

Filiz Namdar Pekiner, ORCID ID:0000-0001-7426-5587

Merve Dönmez Şakır, ORCID ID:0000-0001-6901-6690

Canan Alatlı, ORCID ID:0000-0002-9843-1284

\section{KAYNAKLAR}

1. Yalçın ED, Süslü N, Avcu N. Retromolar trigon skuamöz hücreli karsinom: Olgu sunumu. Atatürk Üniv.Diş Hek.Fak.Derg. 2014; supplement 9;1-5.

2. Bektaş-Kayhan K, Ünür M. Ağız boşluğunda görülen kanserler ve sınıflandırılması. İstanbul Üniversitesi Diş Hekimliği Fakültesi Dergisi 2011; 45:55-63.

3. Özbayrak S, Pekiner FN. Ağız Kanserleri- Erken tanı bakımından dişhekimliği, 1.Baskı İstanbul Quintessence Yayıncılık Ltd.Şti: 2016. p.21-28,6574,151-157.

4. Haksever M. Oral Kavite Kanserlerinde Evreleme, Prognostik Faktörler ve Evreleme Sistemi Üzerine Değerlendirmeler Kocatepe Tıp Dergisi 2013;14: 109-17.

5. Audre K, Schraub S, Mercier M, Bontemps P. Role of alcohol and tobacco in the aetiology of head and neck cancer:A case-control study in the Doubs region of France. Eur J Cancer B Oral Oncol 1995;31B: 301-9.

6. Castellsague $X$, Quintana MJ, Martinez MC, et al. The role of type of tobacco and type of alcoholic beverage in oral carcinogenesis. Int J Cancer 2004;108: 741-9.

7. Chen PC, Kuo C, Pan CC, Chou MY. Risk of oral cancer associated with human papillomavirus infection, betel quid chewing, and cigarette smoking in Taiwan- an integrated molecular and epidemiological study of 58 cases. J Oral Pathol Med 2002;31: 317-22.
8. da Silva ID, Cerri A, Weckx LL. Prevalence of human papillomavirus in squamous cell carcinoma of the tongue. Oral Surg Oral Med Oral Pathol Oral Radiol Endod. 2007;104: 497-500.

9. Figuero Ruiz E, Carretero Peláez MA, Cerero Lapiedra $R$, et al. Effects of the consumption of Alcohol in the oral cavity: Relationship with oral cancer. Med Oral 2004;9:14-23.

10. Gillison ML. Current topics in the epidemiology of oral cavity and oropharyngeal cancers. Head and Neck 2007;29: 779-92.

11. Jovanovic A, Schulten EA, Kostense PJ, et al. Tobacco and alcohol related to the anatomical site of oral squamous cell carcinoma. J Oral Pathol Med 1993,22: 459-62.

12. Morse DE, Psoter WJ, Cleveland D, Cohen D, Mohit-Tabatabai M, Kosis DL, et al. Smoking and drinking in relation to oral cancer and oral epithelial dysplasia. Cancer Causes Control 2007;18:919-29.

13. Neville BW, Day TA. Oral cancer and precancerous lesions. CA Cancer J Clin 2002;52: 195-215.

14. Özbayrak S. Ağız Hastalıkları Atlası Tanı Kriterleri, Ayırıcı Tanı ve Tedavi Yaklaşımları. 3. Baskı, İstanbul, Quintessence Yayıncılık Ltd.Şti.:2010. P.116-120

15. Öztürk B, Coşkun U, Yaman E, Kaya AO, Yıldız R, Benekli $M$, Büyükberber $S$. Oral Kavite Kanserlerinde Risk Faktörleri, Premalign Lezyonlar ve Kemoprevensiyon. Uluslararası HematolojiOnkoloji Dergisi 2009; 19:117-26.

15. Pintos J, Black MJ, Sadeghi N, et al. Human papillomavirus infection and oral cancer: A casecontrol study in Montreal, Canada. Oral Oncol 2008;44: 242-50.

17. Scuibba JJ. Oral cancer. The importance of early diagnosis and treatment. Am J Clin Dermatol 2001;2:239-51.

18. Seoane J, Van der Waal I, Van der Waal RI, Cameselle-Teijeiro J, Antón I, Tardio A, AlcázarOtero JJ, Varela-Centelles P, Diz P. Metastatic tumours to the oral cavity: a survival study with a special focus on gingival metastases. J Clin Periodontol. 2009;36:488-92. 
19. Tandon S, Tudur-Smith C, Riley RD, Boyd MT, Jones TM. A systematic review of p53 as a prognostic factor of survival in squamous cell carcinoma of the four main anatomical subsites of the head and neck. Cancer Epidemiol Biomarkers Prev 2010;19:574-87.

20. Weijers M, Snow GB, Bezemer DP, van dr Wal JE, van der Waal I. The status of the deep surgical margins in tongue and floor of mouth squamous cell carcinoma and risk of local recurrence; an analysis of 68 patients. Int J Oral Maxillofac Surg. 2004;33:146-49.

21. Bagan J, JimenezY, Fernandez J, et al: Malignant transformation of proliferative verrucous leukoplakia to oral squamous cell carcinoma: a series of 55 cases. Oral Oncol 2011;47:732-35.

22. Hashibe M, Jacob BJ, Thomas G, Ramadas K, Mathew B, Sankaranarayanan R, Zhang ZF. Socioeconomic status, lifestyle factors and oral premalignant lesions. Oral Oncology 2003; 39; 664-71.

23. Bettendorf O, Piffko J, Bankfalvi A. Prognostic and predictive factors in oral squamous cell cancer: important tools for planning individual therapy? Oral Oncology, 2004;40:110-19.

24. Napier SS, Speight PM: Natural history of potentially malignant oral lesions and conditions: An overview of the literature. J Oral Pathol Med 2008;37:1-10.

25. Sciubba JJ. Oral cancer the importance of early diagnosis and treatment. Am J Clin Dermatol, 2000;2:239-63.

\section{Yazışma Adresi}

Prof. Dr. Filiz Namdar Pekiner,

Marmara Üniversitesi, Dişhekimliği Fakültesi, Ağız, Diş ve Çene Radyolojisi AD., Başıüyük Sağlık Yerleşkesi Başıüyük Yolu 9/3 34854, Maltepe/ Istanbul - Türkiye e-mail: fpekiner@gmail.com 